\title{
The Impact of Health Education in Curbing Trafficking Amongst Women in Edo State
}

\author{
Ikhioya Grace Olohiomeru (Corresponding author) \\ Department of Physical and Health Education, Faculty of Education \\ Ambrose Alli University, Ekpoma, Edo State, Nigeria \\ E-mail: Graceikhioya@yahoo.com GSM: 08058441101
}

Received: October 16, 2015 Accepted: November 30, 2015 Published: December 4, 2015

doi:10.5296/jsss.v3i1.8448 URL: http://dx.doi.org/10.5296/jsss.v3i1.8448

\begin{abstract}
Trafficking in human is a serious crime and a grave violation of human rights. Trafficking is carried out for different reasons, such as sexual slavery, forced labour, commercial prostitution, organ harvesting amongst others. It has become a great concern in Nigeria and Edo state in particular as a result of the notorious reputation for being one of the leading countries of Africa in human trafficking and there have been several researches carried out to phantom the propelling rationale for the increasing incidence of trafficking especially in women in Edo state. The paper examined the impact of health education in curbing women trafficking in Edo state. The writer discussed the following; what is trafficking in women, prevalence, causes, contributing factors, effects and the objectives of Health Education. It was discovered that the objective of Health Education as stated by Parmars, (2007) as informing the people, motivation of the people and guidance of the people can have positive and great impact in curbing women trafficking. Conclusions were drawn from other areas and recommendations were made.
\end{abstract}

Keyword: Women, Trafficking, Health education, Impact, Curbing

\section{Introduction}

Human trafficking, like money laundering, advanced fee fraud, cyber scams and illicit trade in arms and narcotics has elicited a great concern as a contemporary social problem worldwide (Poulin, 2004). It is considered to be the third largest source of profit for organized crime apart from drugs and arms (UNHCR, 2000). The illegal trade occupies a prominent position among the social ills that pervade the Nigerian Society (Ofuoku, 2010). 
While it may appear that the problem seems more endemic in the southern part of the country, there are indications that no part of the country is completely immune from this social malaise that has ravaged many countries in the world (UNICRI, 2004).

Human trafficking as defined by WHO, (2012) is the recruitment, transportation, transfer, harbouring or receipt of persons, by means of the threat or use of force or other forms of coercion, of abduction, of fraud, of deception, of the abuse of power or of a position of vulnerability or of the giving or receiving of payments or benefits to achieve the consent of a person having control over another person, for the purpose of exploitation.

Women trafficking refer to the recruitment and transportation of women across national or international borders either voluntarily or involuntarily, for sexual or domestic purposes. It also includes the purchase, sale, transfer, receipt or harboring of young girls and women through deception for the purpose of subjecting the women and girls to involuntary servitude (Linus, 2010).

According to Linus, (2010), the phenomenon of the trafficking of women, especially of young girls and women into exploitative sexual and commercial labour, has recently begun to attract local, national and international attention from world leaders, academics, the mass media, advocacy groups, the clergy and humanity in general. This is against the back drop of the fact that the trafficking of women has a number of far-reaching socio-economic, health and political consequences. Several factors, among them poverty, unemployment, ignorance and family size have been implicated as being reasons why women fall easy preys to the antics of traffickers.

The history of human trafficking, including that of the trafficking of women, cannot be completely divorced from the phenomenon of slavery. This is because both involve the acquisition and transportation of humans across local, national and international borders for servitude, with or without the consent of the trafficked person(s) (Linus, 2010).

Okojie, Eghafona, Okojie, Vincent-Osaghae and Kalu, (2003) identified trafficking as a multi-dimensional problem. Foundation of Women's Forum, (1998) recognised the following approaches to addressing the problem:

- A moral problem: This approach sees trafficking in women and prostitution as an evil that should be controlled. Actions against trafficking using this approach aim at controlling and punishing the parties involved. This places women in prostitution at risk of punishment instead of regarding them as victims.

- A criminal problem: The criminal approach aims at introducing heavier punishments, improving international Police cooperation and other measures which will lead to more effective prosecution of offenders. The interests of the women are subordinated to those of prosecution.

- A migration problem: This approach views trafficking as a problem of illegal migration. Actions here are aimed at keeping women at home, stricter border controls, etc. The interest of the State is to keep out undesirable aliens.

- A human rights problem: Treating trafficking in women as a human rights problem can be looked at in two ways. Firstly, forced prostitution is seen as a violation of the human rights of women and should be abolished. The other aspect is that prostitution as such does not 
violate the rights of women, but the conditions women in prostitution live under, such as deceit, debt bondage, blackmail and deprivation of freedom of movement, violate their human rights.

- A public order problem: This approach views trafficking in women and prostitution as a public order issue or a public health issue. Solutions are to increase control by, for example, introducing medical examination.

- A labour issue problem: Trafficking in women is seen as the result of poor legal and social position of women in most societies: as women, as workers and as migrants. The solution is to improve labour opportunities and working conditions, pensions, state benefits, etc., to women in prostitution.

\section{Prevalence of Trafficking in Women}

Precise figures at the global or even local level remain elusive. Reliable data on trafficking are difficult to obtain owing to its illegal, often invisible, nature; the range and severity of trafficking activities; and variations in how trafficking is defined (Oram, 2011).

Like in other countries, only very limited data on the volume of trafficking in women is available in Nigeria. Lack of data has been explained as being a result of the underground and illegal nature of trafficking; lack of anti-trafficking legislation in many countries; the reluctance of victims to report their experiences to the authorities; and the lack of Government priority given to data collection and research (Loconto, 2002). These and other factors also blur the distinction between trafficked persons, extremely vulnerable migrants and exploited labourers. Individuals may be trafficked within their own country or across international borders (USDOS, 2011).

According to UNESCO, (2006), In 2004 US State Department figures indicate that $600,000-800,000$ women and children are trafficked annually across international borders. Approximately $80 \%$ are women and up to $50 \%$ are minors. The vast majority of those trafficked under 18 years of age are girls. Male minors account for only $2 \%$ of trafficking cases. The United Nations estimates a figure closer to 4 million as a total for internationally and internally trafficked people. UNICEF estimates 1,200,000 children were trafficked globally in 2000. Men, women, and children are trafficked for many purposes - sexual exploitation, begging, underpaid and exploited forced labour in the agricultural, manufacturing and construction industries, domestic service and organ harvesting.

Trans-national organized criminal syndicates and networks are responsible for the bulk of human trafficking, which is linked to a range of other trafficking such as drugs, firearms, consumables, and other criminal activities including money laundering, smuggling and political bribery and corruption. Trafficking in humans is a highly lucrative business. Estimated profits are between US \$7-10 billion annually. Crime networks are well organized, flexible and responsive to demand (UN, 2000).

According to Nigerian Division of the International Criminal Police Organization (2000), reported that Nigerian women and girls en-route to Europe spend many months in the deserts of North Africa and are forced into labor and prostitution to survive during the journey. About $92 \%$ of Nigerians trafficked to Europe for prostitution come from Edo State of Nigeria. Initially, most came from Benin City, the capital of Edo State, and from cities in Delta State. 


\section{Purposes of Trafficking in Women and Children in Nigeria}

As outlined by UNESCO, (2004) In Nigeria, persons are trafficked for prostitution, to work as domestic servants, bus conductors, and street traders. They are exploited in agricultural work, brass melting, stone digging and scavenging.

\subsection{Prostitution}

Nigerian women and children are trafficked both internally and externally for sex. In the last decade, thousands of women and young girls were trafficked into the sex industry, especially into Europe, so that many people in Nigeria came to equate trafficking with prostitution alone and not with other forms of labor.

\subsection{Domestic Help}

Urban migration and poverty have saturated the labor market, especially the informal labor market, and led to the systematic reduction of the cost of labor. As a result, cheap labor in the informal sector, particularly domestic labor, grew as the economic crisis obliged every member of the family to work outside their homes to sustain family finances.

Others includes the following; "Diya" or "Blood Money", Begging, Baby Harvesting.

\section{Causes of Human (Women) Trafficking in Nigeria?}

According to UNESCO (2006), the supply and demand equation is typically described in terms of "push" and "pull" factors. These factors have a global resonance, but vary in local emphasis and scale. While armed conflict distorts and magnifies conditions of hardship and insecurity and creates fertile conditions for trafficking in all commodities, it is ultimately poverty, high unemployment and lack of opportunity, the quest for a means of survival, that is the engine driving trafficking in humans. The push/pull factors - two sides of the same coin - factors that make women and girls particularly vulnerable are rooted in systemic gender discrimination. It is important to remember that these explanatory factors can be mutually reinforcing and that some of the causes can also be the consequence of others. More research is required into the mechanics of these causes. Women and girls are more vulnerable to being trafficked because of:

\subsection{Factors Contributing to Supply (Push Factors)}

These factors according to UNIFEM, (2002) includes the following;

- Unequal Access to Education that limits women's opportunities to increase their earnings in more skilled occupations;

- Lack of Legitimate And Fulfilling Employment Opportunities particularly in rural communities;

- Sex-selective migration policies and restrictive emigration policies/laws, instituted often as a "protective" measure, limit women's legitimate migration. Most legal channels of migration offer opportunities in typically male-dominated sectors (construction and agriculture work);

- Less access to information on migration/job opportunities, recruitment channels, and a greater lack of awareness of the risks of migration compared to men;

- Disruption of support systems due to natural and human created catastrophes; and 
- Traditional community attitudes and practices, which tolerate violence against women. (UNIFEM, 2002)

\subsection{Factors Contributing to Demand (Pull Factors)}

These factors according to UNIFEM, (2002) includes the following;

- Women's perceived suitability for work in labour-intensive production and the growing informal sector which is characterized by low wages, casual employment, hazardous work conditions and the absence of collective bargaining mechanisms;

- The increasing demand for foreign workers for domestic and care-giving roles, and lack of adequate regulatory frameworks to support this;

- The growth of the billion-dollar sex and entertainment industry, tolerated as a 'necessary evil' while women in prostitution are criminalized and discriminated against;

- The low risk-high profit nature of trafficking encouraged by a lack of will on the part of enforcement agencies to prosecute traffickers (which includes owners/managers of institutions into which persons are trafficked);

- The ease in controlling and manipulating vulnerable women;

- Lack of access to legal redress or remedies, for victims of traffickers; and

- Devaluation of women and children's human rights. (UNIFEM, 2002)

\subsection{Other Factors Contributing to Trafficking in Women in Edo State and Nigeria}

According to UNODC, (2006), a number of factors contribute to the phenomenon of trafficking in human beings, in particular children, in Edo state and Nigeria. Predominant among these are poverty, large family size, lack of educational opportunities and lack of employment. Other factors facilitating trafficking in persons in Nigeria include ignorance on the part of families and children of the risks involved in trafficking, the high demand for cheap and submissive child labour in the informal economic sector, the desire of youth for emancipation through migration, institutional lapses such as inadequate political commitment, non-existent national legislation against trafficking in human beings, and the absence of a judicial framework allowing for the perpetrators and accomplices of trafficking to be held responsible and punished for their acts. Other contributory factors in trafficking in persons in the region include porous borders, corrupt government officials, involvement of international organized crime groups or networks, limited capacity of or commitment by immigration and law enforcement officers to control trafficking at the borders and lack of political will or desire to enforce existing legislation or mandates (UNODC, 2006).

\section{Health and Other Effects Associated with Trafficking in Women}

As outlined by WHO, (2012), health and other effects of trafficking in women are as followed;

- Poor mental health is a dominant and persistent adverse health effect associated with human trafficking. Psychological consequences include depression; post-traumatic stress disorder and other anxiety disorders; thoughts of suicide; and somatic conditions including disabling physical pain or dysfunction (Koss \& Heslet, 1992). 
- Forced or coerced use of drugs and alcohol is frequent in sex trafficking. Drugs and alcohol may be used as a means to control individuals and increase profits (Zimmerman, 2007; Caouette, 1999) or as a coping method or by the trafficked person as a coping method.

- Imposed social isolation, such as prevention of family contact or restriction of a person's movements, is used to maintain power over people in trafficking situations, as is emotional manipulation by the use of threats and false promises.

- Economic exploitation is widespread. Trafficked people rarely have decision-making power over what they earn and may be charged by traffickers for 'services' or 'supplies' such as housing, clothes, food or transport. These usurious practices often lead to 'debt bondage' (Pearson, 2002).

- Legal insecurities are common for people who travel across borders, particularly when traffickers or employers confiscate identity documents or give false information about rights, including access to health services. This may not only limit people's use of medical services but also lead to unjust deportation or imprisonment (Phinney, 2001). Trafficked people may not be acknowledged as victims of crime but instead treated as violators of migration, labour or prostitution laws and held in detention centres or imprisoned as illegal immigrants.

- $\quad$ Trafficked people who return home may go back to the same difficulties they left but with new health problems and other challenges, such as stigma. For those who try to remain in the location to which they were trafficked, many encounter the insecurities and stresses found in asylum-seeking and refugee populations (Steel, 2007). People who manage to leave a trafficking situation, whether they return to their country of origin or not, are at a notable risk of being trafficked again (Jobe, 2010).

- $\quad$ Trafficked persons are unable to insist upon condom use and may be forced to perform those sexual practices most associated with AIDS transmission. They also are forced to have sex with multiple partners.

- Violence in commercial sex is common, especially where women or children are forced to have sex against their will. Injuries sustained during forced sex may increase vulnerability to HIV transmission.

- $\quad$ The physically immature bodies of young girls are extremely vulnerable to sexual injury. Such injuries increase their risk of infection.

- Many trafficked persons have other sexually transmitted diseases (STDs) due to forced and unsafe sexual activities (Burkhalter, 2003).

\section{Role of Health Education}

The aim of health education is to encourage people to value health as a worthwhile asset and to let them know what they can do as individuals and communities to promote their own health (Lucas \& Gilles, 2003). Health education help to alter altitudes and behaviour in matter concerning health.

Health education as defined by (Parmar, 2007) is a process that informs, motivates and help people to adopt and maintain healthy practices and lifestyle, advocates environmental changes as needed to facilitate this goal and conduct professional training and research to the same end. 
According Parmar, (2007) the main objectives of health are;

- Informing the People: this involves providing the information to the people and thus disseminating scientific knowledge about the prevention of diseases and promotion of health. Exposure to knowledge will remove the barriers of ignorance, prejudices, misconception and superstitions which people have about health and disease.

- Motivation of the People: This objective is concerned with the motivation of the people to change their habits and ways of living. The commonly adopted health practices are detrimental to health have to be changed. Health education should motivate the people for adopting health practices which may keep them free of avoidable disease and improve the quality of life.

- Guidance of the People: Health Education should be provided by a variety of well-trained health education, and communication personnel starting with the physician, people should be encouraged and guided to use the health services available to them judiciously.

\section{Conclusion and Recommendation}

Women trafficking refer to the recruitment and transportation of women across national or international borders either voluntarily or involuntarily, for sexual or domestic purposes. It also includes the purchase, sale, transfer, receipt or harboring of young girls and women through deception for the purpose of subjecting the women and girls to involuntary servitude. Several factors, among them poverty, unemployment, ignorance and family size have been implicated as being reasons why women fall easy preys to the antics of traffickers.

It will be recommended that enlightenment and awareness campaign be organized to sensitive the people generally on implications of trafficking amongst women, programmes should be organized to expose the mode of operations of this traffickers, laws and legislation be enacted to punish offenders and those found guilty, also employments and other alternative sources of income generation should be made available by the government.

\section{References}

Burkhalter, H. (2003). Sex Trafficking and the HIV/AIDS Pandemic, Physicians for Human Rights, Testimony before the House International Relations Committee, pp. 1-2 (www.phrusa.org/campaign/aids/news062403)

Foundation of Women's Forum. (1998). Trafficking in Women for the purpose of sexual exploitation-mapping the situation and existing organizations working in Belarus, Russia, the Baltic and Nordic Stales, Stockholm.

Jobe, A. (2010). The causes and consequences of re-trafficking: evidence from the IOM human trafficking database. Geneva, International Organization for Migration.

Koss, M. P., \& Heslet, L. (1992). Somatic consequences of violence against women. Archives of Family Medicine, 1(1), 53-59. http://dx.doi.org/10.1001/archfami.1.1.53

Loconto, A. (2002). The trafficking of Nigerian women into Italy. TED Case Studies, No. 656, January.

Lucas, A. O., \& Gills, H. M. (2003). Short textbook on Public Health Medicine in the tropics. Book power $4^{\text {th }}$ Edition. 


\section{Macrothink}

Journal of Social Science Studies

ISSN 2329-9150

2016, Vol. 3, No. 1

Ofuoku, A. U. (2010). Human Trafficking in Nigeria and its Implication for Food Security. Int. J. Rural Stud., 17(1), 1-6.

Okojie, E. E., Eghafona, K., Okojie, O., Vincent-Osaghae, G., \& Kalu, V. (2003). Trafficking of Nigerian girls to Italy; Report of field survey in Edo state, Nigeria.

Oram, S. (2001). International law, national policymaking and the health of trafficked people in the UK. Health and Human Rights, 13(2), 7-12.

Parmar, N. S. (2007). Health Education and community pharmacy. Comprehensive text book for diploma and degree students in pharmacy. CBS publishers \& distributors 4596/1A, 11 Daryaganj, New Delhi, 110002, India.

Pearson, E. (2002). Human traffic, human rights: redefining victim protection. London, Anti-slavery International.

Phinney, A. (2001). Trafficking of women and children for sexual exploitation in the Americas. Washington, DC, Inter American Commission of Women (Organization of American States).

Poulin, R. (2004) Globalization and Sex Trade: Trafficking and Commodification of Women and Children. Ca. Women's Stud., 22, 38-43. Report from the Nigerian Division of the International Criminal Police Organization, report dated 25th August 2000.

Steel. (2006). Impact of immigration detention and temporary protection on the mental health of refugees. British Journal of Psychiatry, 188, 58-64.

UN. (2006). Protocol to prevent, suppress and punish trafficking in persons, especially women and children, supplementing the United Nations convention against transnational organized crime. General Assembly resolution 55/25. New York, NY, United Nations General Assembly.

UNESCO. (2004). Interview of Mallam Mohammed Garuba by Dr. Yakubu Zachariah during the UNESCO research on human trafficking in West Africa 2004.

UNESCO. (2006). Human trafficking in Nigeria: root causes and recommendations. Policy Paper Poverty Series No. 14.2 (E). Paris: UNESCO

United Nations Interregional Crime and Justice Research (UNICRI). (2004). Trafficking of Nigerian Girls to Italy UNICRI publication. pp. 23 -24

United Nations High Commission for Refugees (UNHCR). (2000). A Multi-billion Dollar Trade in Human (In) Refugee UNHCR, Geneva. pp. 18-19

UNIFEM. (2002). Trafficking in Persons: A gender and rights perspective, Briefing Kit.

UNODC. (2006). Trafficking in persons: global patterns, New York: UNODC

USDOS. (2011). Trafficking in Persons Report 2011. Washington, DC, United States of America Department of State.

World Health Organization. (2012). Understanding and addressing violence against women. http://www.who.int/reproductivehealth/publications/violence/en/index.html

Zimmerman, C. (2007). Health risks and consequences of trafficked women in Europe: conceptual models, qualitative and quantitative findings. London, London School of Hygiene and Tropical Medicine. 


\section{Macrothink}

Journal of Social Science Studies

ISSN 2329-9150

\section{Copyright Disclaimer}

Copyright reserved by the author(s).

This article is an open-access article distributed under the terms and conditions of the Creative Commons Attribution license (http://creativecommons.org/licenses/by/3.0/). 